\title{
Fluoride Rinses, Gels and Foams: An Update of Controlled Clinical Trials
}

\author{
Svante Twetman Mette K. Keller \\ Department of Odontology, School of Dentistry, Faculty of Health and Medical Sciences, University of Copenhagen, \\ Copenhagen, Denmark
}

\section{Key Words}

Caries · Fluoride $\cdot$ Prevention · Root caries $\cdot$ Schoolchildren

\begin{abstract}
Aim: The aim of this conference paper was to systematically review the quality of evidence and summarize the findings of clinical trials published after 2002 using fluoride mouth rinses, fluoride gels or foams for the prevention of dental caries. Methods: Relevant papers were selected after an electronic search for literature published in English between 2003 and 2014. The included papers were assessed for their risk of bias and the results were narratively synthesized due to study heterogeneity. The quality of evidence was expressed according to GRADE. Results: A total of 19 papers were included ( 6 on fluoride mouth rinse, 10 on fluoride gel and 3 on fluoride foam); 6 had a low risk of bias while 2 had a moderate risk. All fluoride measures appeared to be beneficial in preventing crown caries and reversing root caries, but the quality of evidence was graded as low for fluoride mouth rinse, moderate for fluoride gel and very low for acidulated fluoride foam. No conclusions could be drawn on the cost-effectiveness. Conclusions: This review, covering the recent decade, has further substantiated the evidence for a caries-preventive effect of fluoride mouth rinse, fluoride gel and foam, previously established in systematic reviews. The
\end{abstract}

lack of clinical trials free from bias is, however, still a concern, especially for fluoride mouth rinses and fluoride foam. There is also a scientific knowledge gap on the benefit and optimal use of these fluoride supplements in combination with daily tooth brushing with fluoride toothpaste.

(c) 2016 The Author(s)

Published by S. Karger AG, Basel

There is a broad consensus that fluoride prevents caries in children and adults of all ages [Griffin et al., 2007; Marinho, 2009; Gibson et al., 2011]. In this context, selfapplied and professional supplements play a significant role. Fluoride mouth rinse has a long tradition as a schoolbased measure worldwide, but the procedure is also commonly recommended for domestic use for subjects at caries risk, e.g. patients with fixed orthodontic appliances and vulnerable elderly [Rugg-Gunn and Bánóczy, 2013]. Systematic reviews have established a caries-preventive fraction of 24-29\% when fluoride mouth rinses are compared with placebo in permanent teeth in schoolchildren and adolescents, as well as for root caries reversal/arrest in older adults [Marinho et al., 2003a; Twetman et al.,

Conference paper 'Beyond 1,000 ppm - High fluorides and fluoride boosters to secure oral health'.

\section{KARGER \\ E-Mail karger@karger.com} www.karger.com/cre

\section{() 2016 The Author(s) \\ Published by S. Karger AG, Basel 0008-6568/16/0507-0038 $\$ 39.50 / 0$}

This article is licensed under the Creative Commons AttributionNonCommercial-NoDerivatives 4.0 International License (CC BYNC-ND) (http://www.karger.com/Services/OpenAccessLicense) Usage and distribution for commercial purposes as well as any distribution of modified material requires written permission. 
2004]. The quality of evidence was, however, rated as limited [Twetman et al., 2004]. Fluoride gels are professionally applied in trays and display a preventive fraction of $21 \%$ compared with placebo [Marinho et al., 2003b]. Neutral or acidulated fluoride foam is a professional option to gel but less studied in clinical trials. An updated systematic review of topical fluorides for caries with clinical recommendations has recently been released by the ADA Center for Evidence-Based Dentistry [Weyant et al., 2013]. The strength of the clinical recommendations were moderate for the daily or weekly use of fluoride mouth rinses in school-aged children, while the use of gels and foams was questioned, especially for coronal caries in adults and root caries. Since the methodology in systematic reviews might differ with respect to inclusion criteria and quality assessment, continuous updates and critical appraisals of the literature may be of importance in order to reinforce evidence and identify possible knowledge gaps. The aim of this conference paper was to examine and summarize the findings of controlled clinical trials published after 2002 using fluoride mouth rinses, fluoride gels or foam for the prevention of dental caries.

\section{Methods}

Search Strategy and Inclusion Criteria

The systematic reviews from the Cochrane Library and The Swedish Council of Technology Assessment in Health Care formed the basis for this paper. Three sources were searched from 2003 throughout January 2015 for reports on controlled clinical trials: PubMed, the Cochrane Library and the Trip Database. The key words were 'fluoride mouth rinse', 'fluoride mouth wash', 'fluoride gel', 'fluoride foam' and 'incipient lesions', 'caries', 'dental decay', 'root caries' in various combinations. The full search strategy is shown in online supplement 1 (for all online suppl. material, see www.karger.com/doi/10.1159/000439180). The abstract list, containing 219 hits, was independently assessed by the two authors and papers of potential relevance were selected. Diverging opinions were solved in consensus. To be considered for inclusion, a full description of a controlled clinical trial (randomized or non-randomized) including more than 40 subjects in each arm was needed. Furthermore, a caries end point (prevalence, incidence, increment, progression, regression) expressed with continuous or categorical data from a clinical and/or radiographic examination was required. In addition, health-economic evaluations were included. Only papers published in English were accepted. Multi-content rinses, gels and foams, such as fluoride combined with antibacterial agents, were disregarded in this review. Likewise, papers describing in situ studies, artificial caries lesions and mouth rinses, gels or foam application as part of a comprehensive preventive programme (except fluoride toothpaste) were not taken into account. The reference lists of accepted papers and systematic reviews were hand-searched for additional literature.

Fluoride Rinse, Gel and Foam
Table 1. Quality of evidence according to GRADE [Guyatt et al., 2011]

High $(\oplus \oplus \oplus \oplus)$ : based on high- or moderate-quality studies containing no factors that weaken the overall judgment

Moderate $(\oplus \oplus \oplus \bigcirc)$ : based on high- or moderate-quality studies containing isolated factors that weaken the overall judgment

Low $(\oplus \oplus \bigcirc \bigcirc)$ : based on high- or moderate-quality studies containing factors that weaken the overall judgment

Very low $(\oplus \bigcirc \bigcirc \bigcirc)$ : the evidence base is insufficient when scientific evidence is lacking; quality of available studies is poor or studies of similar quality are contradictory

\section{Data Extraction}

Key data from the accepted studies were extracted independently by both authors and compiled in tables. Due to the low number and diversity of the included studies, a narrative descriptive synthesis was carried out. When possible, the effect of the selected measures was calculated as the difference between caries increment or prevalence in the control group and the experimental group divided by the increment or prevalence in the control group. This preventive fraction was expressed as percent.

\section{Quality Assessment}

The quality of the selected publications was assessed according to predetermined criteria for methodology and performance. The criteria from the Cochrane handbook for interventions [Higgins et al., 2011] was used and the risk of bias for each paper was graded as 'low', 'moderate' or 'high'. The quality of evidence was rated with the GRADE tool [Guyatt et al., 2011] in four categories, as shown in table 1 . Studies describing a cost analysis of the various programmes were not quality assessed.

\section{Results}

In total, 19 publications describing 17 clinical trials were accepted and quality assessed, as presented in figure 1. In addition, 4 papers on health economy were included. Excluded clinical studies with caries and/or lesion remineralization as end points are listed in the online supplementary material with the main reason for exclusion (online supplements 2 and 3 ).

\section{Fluoride Mouth Rinse}

Fluoride mouth rinses are typically based on neutral sodium fluoride solutions ranging from 0.05 to $0.2 \%$ (225$1,000 \mathrm{ppm}$ ) and intended for subjects 6 years of age and over. In Europe, amine and stannous fluoride formulations are also available. The conclusions from the Cochrane review were based on 34 trials [Marinho et al., 2003a]. In the 
Table 2. Summary of controlled clinical trials on the effect of fluoride mouth rinses

\begin{tabular}{|c|c|c|c|c|c|c|c|}
\hline First author [year] & Design & $\begin{array}{l}\text { Number; } \\
\text { duration }\end{array}$ & $\begin{array}{l}\text { Age, } \\
\text { years }\end{array}$ & $\begin{array}{l}\text { Intervention; } \\
\text { frequency; } \\
\text { concentration }\end{array}$ & Control & $\begin{array}{l}\text { Preventive } \\
\text { fraction }\end{array}$ & Risk of bias \\
\hline \multicolumn{8}{|l|}{ School-based rinsing } \\
\hline Moberg Sköld [2005] & RCT & $\begin{array}{l}269 ; \\
3 \text { years }\end{array}$ & $13-16$ & $\begin{array}{l}\text { SB FMR; } 1 / 14 \text { days; } \\
0.2 \% \mathrm{NaF}\end{array}$ & no FMR & $41 \%^{\mathrm{a}}$ & moderate \\
\hline Levin [2009] & cohort & 1,333 & 5,11 & $\begin{array}{l}\text { SB FMR; } 1 / 14 \text { days; } \\
0.2 \% \mathrm{NaF}\end{array}$ & no FMR & OR $0.79^{\mathrm{b}}$ & high \\
\hline Takeuchi [2012] & CCT & $\begin{array}{l}109 ; \\
6 \text { years }\end{array}$ & 10 & $\begin{array}{l}\text { SB FMR; } 1 \text { /week; } \\
0.2 \% \mathrm{NaF}\end{array}$ & no FMR & $51 \%$ & high \\
\hline \multicolumn{8}{|l|}{ Root caries } \\
\hline Wyatt [2004] & RCT & $\begin{array}{l}247 ; \\
2 \text { years }\end{array}$ & 83 (mean) & $\begin{array}{l}\text { FMR; 1/day; } \\
0.09 \% \mathrm{NaF}\end{array}$ & placebo & $24 \%^{\mathrm{d}}$ & high \\
\hline
\end{tabular}

$\mathrm{PF}=$ Preventive fraction; $\mathrm{SB}=$ school-based $\mathrm{FMR}=$ fluoride mouth rinse $\mathrm{CCT}=$ controlled clinical trial.

${ }^{a}$ Proximal surfaces from bitewing radiographs. ${ }^{b}$ Odds for a tooth being decayed (95\% CI 0.65-0.96). ${ }^{c}$ Risk of developing caries (95\% CI 0.26-0.85). ${ }^{\mathrm{d}}$ Most pronounced in reversing and preventing root surfaces. ${ }^{\mathrm{e}}$ Root caries reversals.

Fig. 1. Flowchart of the literature.

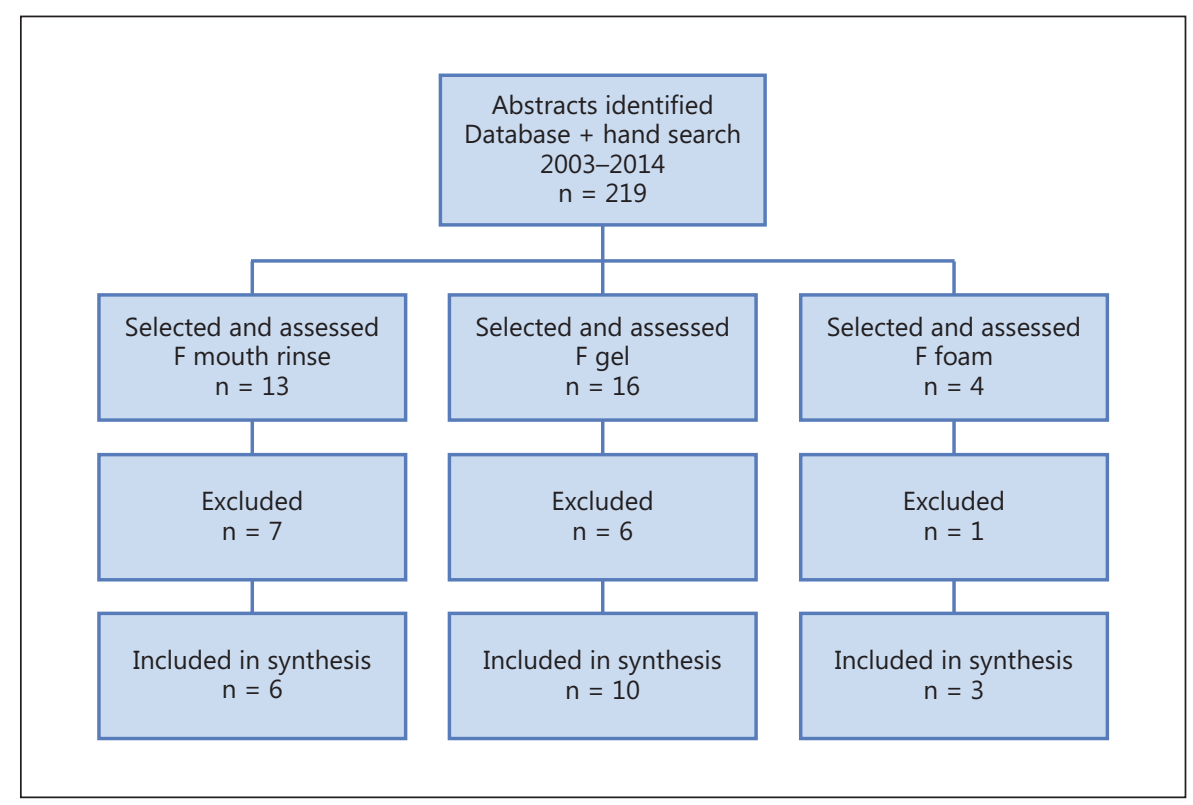

present review, 6 further studies were included, of which 4 dealt with schoolchildren and 2 with the management of root caries (table 2). The studies were small- to mediumsized and performed in Canada, Scotland, Sweden, Malaysia and the Kingdom of Tonga. One study was rated as being of moderate risk of bias while the rest were assessed with high risk. The school-based programmes utilized weekly or bi-weekly $0.2 \% \mathrm{NaF}$ rinses compared with no rinses and the results were generally in favour of the rinses. Notably, the results obtained in the Swedish study were obtained in a 'low to medium caries risk area' with selfreported use of fluoride toothpaste twice daily and annual 
Table 3. Summary of controlled clinical trials on the effect of fluoride gels applied in trays

\begin{tabular}{|c|c|c|c|c|c|c|c|}
\hline First author [year] & Design & $\begin{array}{l}\text { Number; } \\
\text { duration }\end{array}$ & $\begin{array}{l}\text { Age, } \\
\text { years }\end{array}$ & $\begin{array}{l}\text { Intervention; } \\
\text { frequency }\end{array}$ & Control & $\begin{array}{l}\text { Preventive } \\
\text { fraction }\end{array}$ & Risk of bias \\
\hline van Rijkom [2004] & RCT & $\begin{array}{l}773 ; \\
4 \text { years }\end{array}$ & $4-6$ & $\begin{array}{l}\text { NaF gel }{ }^{\mathrm{a}} \text {; } \\
\text { bi-annul }\end{array}$ & placebo & $26 \%{ }^{\mathrm{b}}$ & low \\
\hline Truin [2005a] & $\mathrm{RCT}$ & $\begin{array}{l}773 ; \\
4 \text { years }\end{array}$ & $4-6$ & $\begin{array}{l}\text { NaF gela } \\
\text { bi-annual }\end{array}$ & placebo & $22 \%^{\mathrm{c}}$ & low \\
\hline Truin [2005b] & $\mathrm{RCT}$ & $\begin{array}{l}594 ; \\
4 \text { years }\end{array}$ & $9-11$ & $\begin{array}{l}\mathrm{NaF}_{\text {gela }}^{\mathrm{a}} \\
\text { bi-annual }\end{array}$ & placebo & $18 \%$ & low \\
\hline Jiang [2005a] & $\begin{array}{l}\text { cluster } \\
\text { RCT }\end{array}$ & $\begin{array}{l}661 ; \\
24 \text { months }\end{array}$ & $6-7$ & $\begin{array}{l}\text { APF geld } \\
\text { bi-annual }^{\text {di }}\end{array}$ & no gel & $37 \%^{\mathrm{b}}$ & high \\
\hline Ferreira [2005] & $\mathrm{RCT}$ & $\begin{array}{l}307 ; \\
3 \text { months }\end{array}$ & 12 & $\begin{array}{l}\text { APF geld; } \\
\text { weekly }\end{array}$ & placebo & n.s. ${ }^{e}$ & high \\
\hline Truin [2007] & $\mathrm{RCT}$ & $\begin{array}{l}517 ; \\
4 \text { years }\end{array}$ & $9-11$ & $\begin{array}{l}\mathrm{NaF}_{\text {gel }}^{\mathrm{a}} \text {; } \\
\text { bi-annual }\end{array}$ & placebo & $23 \%^{\mathrm{f}}$ & low \\
\hline Andruskeviciene [2008] & $\mathrm{RCT}$ & $\begin{array}{l}411 ; \\
3 \text { years }\end{array}$ & 3 & $\begin{array}{l}\text { APF geld; } \\
\text { 3/year }\end{array}$ & no gel & $60 \%$ & high \\
\hline Ersin [2008] & RCT & $\begin{array}{l}99 ; \\
2 \text { years }\end{array}$ & $11-13$ & $\begin{array}{l}\text { NaF gela; }^{\mathrm{a}} \\
\text { bi-annual }\end{array}$ & $\mathrm{OHE}^{\mathrm{g}}$ & n.s. & high \\
\hline Stokes [2011] & RCT & $\begin{array}{l}1,075 \\
2 \text { years }\end{array}$ & $12-13$ & $\begin{array}{l}\mathrm{NaF}_{\text {gel }}{ }^{\mathrm{a}} \text {; } \\
2 / \text { week, in school }\end{array}$ & $\begin{array}{l}\text { NaF gel, } \\
\text { 1/week, } \\
\text { domestic }\end{array}$ & $14-26 \%$ & low \\
\hline Agrawal [2011] & $\begin{array}{l}\text { cluster } \\
\text { RCT }\end{array}$ & $\begin{array}{l}257 ; \\
1 \text { year }\end{array}$ & $9-16$ & $\begin{array}{l}\text { APF geld; } \\
\text { bi-annual }\end{array}$ & OHE & $61 \%^{\mathrm{h}}$ & high \\
\hline
\end{tabular}

${ }^{a} 1 \%$ NaF gel. ${ }^{b}$ Dentin caries only. ${ }^{\mathrm{c}}$ Re-analysis of van Rijkom et al. [2004] including initial lesions. ${ }^{\mathrm{d}} 1.23 \%$ APF gel. ${ }^{\mathrm{e}}$ No significant difference, white spot lesion arrest. ${ }^{\mathrm{f}}$ Re-analysis of Truin et al. [2005b] including initial lesions. ${ }^{\mathrm{g}}$ Oral health education programme. $\mathrm{h}$ Incipient lesions only, no significant effect on DMFS.

applications of a fluoride varnish [Moberg Sköld et al., 2005]. Another interesting observation from Scotland was that the mean prevalence of cavitated lesions was higher for non-rinsing subjects than for fluoride rinsers in all socioeconomic categories [Levin et al., 2009]. One study in adults investigated daily rinses with $0.09 \% \mathrm{NaF}$ in institutionalized elderly and the net incidence of both crown and root caries was significantly reduced over a 2-year period [Wyatt and MacEntee, 2004]. A second adult study evaluated the effect of twice-daily amine fluoride rinses as an addition to the daily use of fluoride toothpaste on the reversal of primary root caries lesions [Petersson et al., 2007] and the rinses seemed to boost the arresting effect. The overall caries-preventive effects in the recent studies were mainly of the same magnitude as those suggested in previous systematic reviews. The quality of evidence, however, was still to be regarded as low $(\oplus \oplus \bigcirc \bigcirc)$.

\section{Fluoride Gel}

In the USA, flavoured acidulated phosphate fluoride (APF) gels and foams were the most widely used office- applied topical agents from the late 1960s until the 2000s, when they gradually were replaced by fluoride varnishes [Newbrun, 2011]. The systematic review by Marinho et al. [2003b] was based on 23 studies and this updated literature search revealed 10 additional fluoride gel publications from 8 clinical trials published after 2002 (table 3). All study groups consisted of children; 4 trials employed a neutral sodium fluoride gel and 4 an APF gel. The risk of bias was contrasting; 5 papers had a low risk and 5 had a high risk. The outcome was generally beneficial for the sodium fluoride gel with a preventive fraction around 18$26 \%$, albeit some authors concluded that this reduction was 'not clinically relevant' [van Rijkom et al., 2004; Truijn and van 't Hof, 2005a]. Two studies displayed nonsignificant differences between the test and control groups; in 1 study, the APF gel applications were additional to supervised tooth brushing with fluoride toothpaste [Ferreira et al., 2005] and the other compared sodium fluoride gel applications with a comprehensive oral health programme in children [Ersin et al., 2008]. The most recent contribution [Stokes et al., 2011] showed a small advan- 
Table 4. Summary of controlled clinical trials on the effect of APF foam (1.23\%, pH 3.5) applied in trays

\begin{tabular}{|c|c|c|c|c|c|c|c|}
\hline Jiang [2005a] & cluster RCT & $\begin{array}{l}661 ; \\
24 \text { months }\end{array}$ & $6-7$ & $\begin{array}{l}\text { APF foam; } \\
\text { bi-annual }\end{array}$ & no treatment & $41 \%^{\mathrm{a}}$ & high \\
\hline Jiang [2005b] & cluster RCT & $\begin{array}{l}392 \\
24 \text { months }\end{array}$ & $3-4$ & $\begin{array}{l}\text { APF foam; } \\
\text { bi-annual }\end{array}$ & placebo & $24 \%$ & moderate \\
\hline Jiang [2013] & $\mathrm{RCT}$ & $\begin{array}{l}100 ; \\
18 \text { months }\end{array}$ & $10-20$ & $\begin{array}{l}\text { APF foam; } \\
\text { bi-monthly }\end{array}$ & placebo & $76 \%{ }^{b}$ & low \\
\hline
\end{tabular}

${ }^{\mathrm{a}}$ Limited to smooth surfaces on 1st permanent molars. ${ }^{\mathrm{b}}$ Increment of white spot lesions adjacent to fixed orthodontic brackets.

tage of twice-weekly supervised brushing with a self-applied high-fluoride gel (12,500 ppm) on the increment of dentin lesions in comparison with a once-weekly domestic use. Collectively, the included trials on fluoride gel provided evidence of moderate quality $(\oplus \oplus \oplus \bigcirc)$ that professional and self-applied fluoride gels are associated with a clear reduction in caries increment in the young permanent dentition. There was no information retrieved to question the safety of fluoride gels.

\section{Fluoride Foam}

The APF foam has the same fluoride concentration $(12,300 \mathrm{ppm})$ and $\mathrm{pH}$ as APF gels. Typically, the foam is professionally applied in a trimmed sponge-lined tray and the patient is asked to keep biting in the tray for $4 \mathrm{~min}$ while leaning forward. The advantage with the foam compared with the gel is that only one fifth of the amount by weight is needed for an adequate coverage of the teeth. Three studies from China involving children and adolescents were included and summarized in table 4 . The preventive fraction was $24 \%$ in the primary dentition [Jiang et al., 2005b], 41\% for smooth surfaces of first permanent molars [Jiang et al., 2005a] and 76\% concerning the increment of white spot lesions around orthodontic brackets [Jiang et al., 2013]. Notably, no preventive effect was displayed in fissures located on occlusal surfaces. Furthermore, in all study groups, the tooth-brushing habits were highly irregular and less than $50 \%$ used fluoride toothpaste. Although the external validity was limited, it seems that professional applications of fluoride foam may have a caries-preventive potential of the same magnitude as fluoride gel. The quality of evidence must, however, be regarded as very low $(\oplus \bigcirc \bigcirc \bigcirc)$ due to the small number of studies available and the fact that all originate from one single research group.

\section{Cost Efficacy}

The literature concerning health-economy was scarce and not more than 4 relevant papers were identified. In a Swedish study, the 'natural course' of proximal caries progression was modelled during 4-8 years after 3-year school-based fluoride varnish and fluoride mouth rinse programmes in schoolchildren [Sköld et al., 2008]. The results suggested that the fluoride varnish strategy had a better outcome at $50 \%$ lower costs. On the other hand, school-based fluoride mouth rinse programmes may be cheaper than supervised tooth-brushing programmes [Chen et al., 2010]. In Chile, Mariño et al. [2012] compared the costs required to prevent 1 carious tooth among schoolchildren with various preventive measures and found that salt fluoridation was the most costeffective, with APF gel ranked as the least cost-effective. Furthermore, fluoride varnish applications were found to take less time and resulted in fewer signs of discomfort than foam in high-risk children [Hawkins et al., 2004]. Although the above-mentioned cost analyses may not fully mirror all direct, indirect and tangible costs of caries prevention, the data might be helpful and suggestive to policymakers and community oral health planners.

\section{Discussion}

This 12-year update revealed only 19 'new' clinical trials concerning fluoride mouth rinse, fluoride gel and foam, which certainly indicates that these research areas are far from being 'hot topics'. An explanation could be that the caries-preventive effect of fluoride is already so obvious that further studies are a waste of time and money. However, a main concern was that the scientific
Twetman/Keller 
quality of many of the recent studies was suboptimal and, thus, very little was added to our evidence-based knowledge. This was especially true for fluoride mouth rinses since this is a procedure that is widely recommended in textbooks and by professionals, especially for patients with increased risk [Weyant et al., 2013]. It can be argued that fluoride mouth rinses are out of topic for this conference since they seldom are 'beyond' 1,000 ppm F. On the other hand, there are still some diverging opinions whether or not school-based fluoride rinses are beneficial in populations with regular use of fluoride toothpaste [Twetman et al., 2004; Moberg Sköld et al., 2005; Marinho, 2009] or whether this measure only 'pays off' in vulnerable risk groups. Levin et al. [2009] did not demonstrate a socioeconomic gradient of efficacy, while Divaris et al. [2012] found the most substantial caries-preventive benefits from long-term fluoride mouth rinse participation were obtained in high-risk schools. A recent systematic review has suggested that root caries patients can benefit from fluoride mouth rinses compared with a placebo rinse but the conclusion was based on very few well conducted RCTs [Wierichs and Meyer-Lueckel, 2015].

The relatively low interest in fluoride gels and foams may be understood in the light of the global increase in fluoride varnishes, with subsequent research attention. The results from the trials included in this review underlined that the preventive fraction from the gels and foams generally is inferior to that of fluoride varnish [Marinho et al., 2013], although no recent head-to-head comparisons seemed to be available. For the individual patient, however, a variety of professional fluorides is essential in order to meet personal preferences, flavour and convenience of application. Such factors, along with costs and reimbursement systems, are likely to be more important for the patient than minor differences in effectiveness. The lack of gel and foam data covering adults and vulnerable elderly was striking, as well as the shortage of benefit-harm assessments and economical evaluations. Elderly patients often have an impaired saliva function due to aging and polypharmacy and perceive tooth brushing as physically difficult. In these cases, fluoride mouth rinses and self-applied fluoride gels or foams could be an option that merits further clinical research.

This update was conducted mainly in accordance with the methodology suggested by Siwek et al. [2002] and the literature search was made to overlap the Cochrane reviews summarized by Marinho [2009] and the systematic review of Twetman et al. [2004]. The English language restriction may have overlooked foreign clinical reports, although this risk might be small according to previous experiences [Morrison et al., 2012]. Another possible shortage was that in situ studies and investigations reporting surrogate end points, e.g. fluoride levels in saliva and plaque after applications, were disregarded. Such studies can never build evidence but indicate how effective a particular regimen can be. For example, Zero et al. [1988] reported fluoride mouth rinsing to be superior to fluoride tooth brushing when it came to residual levels in saliva. This could indicate that tooth brushing with its partial plaque removal should be followed by a fluoride rinse for the remineralization of caries lesions, as suggested by ten Cate [2013].

In conclusion, this review, covering the recent decade, has further substantiated the evidence base for a cariespreventive effect of fluoride mouth rinse, fluoride gel and foam that has previously been established in systematic reviews. The quality of evidence according to GRADE could, however, not be altered. The lack of clinical trials free from bias is still a concern, especially for fluoride mouth rinses and fluoride foam. There is also a scientific knowledge gap on the benefit and optimal use of these fluoride supplements in combination with daily tooth brushing in adults and the elderly.

\section{Disclosure Statement}

The first author received a fee from Colgate in connection with this conference presentation and has previously received research grants from several oral care companies. The second author has no conflicts of interest to declare.

References

Agrawal N, Pushpanjali K: Feasibility of including APF gel application in a school oral health promotion program as a caries-preventive agent: a community intervention trial. J Oral Sci 2011;53:185-191.

Andruskeviciene V, Milciuviene S, Bendoraitiene E, Saldunaite K, Vasiliauskiene I, Slabsinskiene E, Narbutaite J: Oral health status and effectiveness of caries prevention programme in kindergartens in Kaunas city (Lithuania). Oral Health Prev Dent 2008;6:343-348.

Chen CJ, Ling KS, Esa R, Chia JC, Eddy A, Yaw SL: A school-based fluoride mouth rinsing programme in Sarawak: a 3-year field study. Community Dent Oral Epidemiol 2010;38: 310-314.

Divaris K, Rozier RG, King RS: Effectiveness of a school-based fluoride mouthrinse program. J Dent Res 2012;91:282-287. 
Ersin NK, Eden E, Eronat N, Totu FI, Ates M: Effectiveness of 2-year application of schoolbased chlorhexidine varnish, sodium fluoride gel, and dental health education programs in high-risk adolescents. Quintessence Int 2008; 39:e45-e51.

Ferreira MA, Latorre Mdo R, Rodrigues CS, Lima KC: Effect of regular fluoride gel application on incipient carious lesions. Oral Health Prev Dent 2005;3:141-149.

Gibson G, Jurasic MM, Wehler CJ, Jones JA: Supplemental fluoride use for moderate and high caries risk adults: a systematic review. J Public Health Dent 2011;71:171-184.

Griffin SO, Regnier E, Griffin PM, Huntley V: Effectiveness of fluoride in preventing caries in adults. J Dent Res 2007;86:410-415.

Guyatt G, Oxman AD, Akl EA, Kunz R, Vist G, Brozek J, Norris S, Falck-Ytter Y, Glasziou P, DeBeer H, Jaeschke R, Rind D, Meerpohl J, Dahm P, Schünemann HJ: GRADE guidelines. 1. Introduction - GRADE evidence profiles and summary of findings tables. J Clin Epidemiol 2011;64:383-394.

Hawkins R, Noble J, Locker D, Wiebe D, Murray $\mathrm{H}$, Wiebe P, Frosina C, Clarke M: A comparison of the costs and patient acceptability of professionally applied topical fluoride foam and varnish. J Public Health Dent 2004;64: 106-110.

Higgins JP, Altman DG, Gøtzsche PC, Jüni P, Moher D, Oxman AD, Savovic J, Schulz KF, Weeks L, Sterne JA; Cochrane Bias Methods Group; Cochrane Statistical Methods Group: The Cochrane Collaboration's tool for assessing risk of bias in randomised trials. BMJ 2011;343: d5928.

Jiang H, Bian Z, Tai BJ, Du MQ, Peng B: The effect of a bi-annual professional application of APF foam on dental caries increment in primary teeth: 24-month clinical trial. J Dent Res 2005b;84:265-268.

Jiang H, Hua F, Yao L, Tai B, Du M: Effect of $1.23 \%$ acidulated phosphate fluoride foam on white spot lesions in orthodontic patients: a randomized trial. Pediatr Dent 2013;35:275278.

Jiang H, Tai B, Du M, Peng B: Effect of professional application of APF foam on caries reduction in permanent first molars in 6- to 7-year-old children: 24 -month clinical trial. J Dent 2005a;33:469-473.

Levin KA, Jones CM, Wight C, Valentine C, Topping GV, Naysmith R: Fluoride rinsing and dental health inequalities in 11-year-old children: an evaluation of a supervised schoolbased fluoride rinsing programme in Edin- burgh. Community Dent Oral Epidemiol 2009;37:19-26.

Marinho VC: Cochrane reviews of randomized trials of fluoride therapies for preventing dental caries. Eur Arch Paediatr Dent 2009;10: 183-191.

Marinho VC, Higgins JP, Logan S, Sheiham A: Fluoride mouthrinses for preventing dental caries in children and adolescents. Cochrane Database Syst Rev 2003a;3:CD002284.

Marinho VC, Higgins JP, Logan S, Sheiham A: Systematic review of controlled trials on the effectiveness of fluoride gels for the prevention of dental caries in children. J Dent Educ 2003b;67:448-458.

Marinho VC, Worthington HV, Walsh T, Clarkson JE: Fluoride varnishes for preventing dental caries in children and adolescents. Cochrane Database Syst Rev 2013;7:CD002279.

Mariño R, Fajardo J, Morgan M: Cost-effectiveness models for dental caries prevention programmes among Chilean schoolchildren. Community Dent Health 2012;29:302-308.

Moberg Sköld U, Birkhed D, Borg E, Petersson LG: Approximal caries development in adolescents with low to moderate caries risk after different 3-year school-based supervised fluoride mouth rinsing programmes. Caries Res 2005;39:529-535.

Morrison A, Polisena J, Husereau D, Moulton K, Clark M, Fiander M, Mierzwinski-Urban M, Clifford T, Hutton B, Rabb D: The effect of English-language restriction on systematic review-based meta-analyses: a systematic review of empirical studies. Int J Technol Assess Health Care 2012;28:138-144.

Newbrun E: Finn Brudevold: discovery of acidulated phosphate fluoride in caries prevention. J Dent Res 2011;90:977-980.

Petersson LG, Hakestam U, Baigi A, Lynch E: Remineralisation of primary root caries lesions using amine fluoride rinse and dentifrice twice a day. Am J Dent 2007;20:93-96.

Rugg-Gunn A, Bánóczy J: Fluoride toothpastes and fluoride mouthrinses for home use. Acta Med Acad 2013;42:168-178.

Siwek J, Gourlay ML, Slawson DC, Shaughnessy AF: How to write an evidence-based clinical review article. Am Fam Physician 2002;65: 251-258.

Sköld UM, Petersson LG, Birkhed D, Norlund A: Cost-analysis of school-based fluoride varnish and fluoride rinsing programs. Acta Odontol Scand 2008;66:286-292.

Stokes E, Ashcroft A, Burnside G, Mohindra T, Pine CM: Randomised controlled trial of the efficacy of a high-fluoride gel self-applied by toothbrushing in children at high caries risk. Caries Res 2011;45:475-485.

Takeuchi R, Kawamura K, Kawamura S, Endoh M, Tomiki S, Taguchi C, Kobayashi S: Effect of school-based fluoride mouth-rinsing on dental caries incidence among schoolchildren in the Kingdom of Tonga. J Oral Sci 2012;54: 343-347.

ten Cate JM: Contemporary perspective on the use of fluoride products in caries prevention. Br Dent J 2013;214:161-167.

Truin GJ, van 't Hof MA: Caries prevention by professional fluoride gel application on enamel and dentinal lesions in low-caries children. Caries Res 2005a;39:236-240.

Truin GJ, van 't Hof MA: Professionally applied fluoride gel in low-caries 10.5-year-olds. J Dent Res 2005b;84:418-421.

Truin GJ, van 't Hof M: The effect of fluoride gel on incipient carious lesions in a low-caries child population. Community Dent Oral Epidemiol 2007;35:250-254.

Twetman S, Petersson L, Axelsson S, Dahlgren H, Holm AK, Källestål C, Lagerlöf F, Lingström P, Mejàre I, Nordenram G, Norlund A, Söder B: Caries-preventive effect of sodium fluoride mouthrinses: a systematic review of controlled clinical trials. Acta Odontol Scand 2004;62:223-230.

van Rijkom HM, Truin GJ, van 't Hof MA: Cariesinhibiting effect of professional fluoride gel application in low-caries children initially aged 4.5-6.5 years. Caries Res 2004;38:115-123.

Weyant RJ, Tracy SL, Anselmo TT, Beltrán-Aguilar ED, Donly KJ, Frese WA, Hujoel PP, Iafolla T, Kohn W, Kumar J, Levy SM, Tinanoff N, Wright JT, Zero D, Aravamudhan K, Frantsve-Hawley J, Meyer DM; American Dental Association Council on Scientific Affairs Expert Panel on Topical Fluoride Caries Preventive Agents: Topical fluoride for caries prevention: executive summary of the updated clinical recommendations and supporting systematic review. J Am Dent Assoc 2013;144: 1279-1291.

Wierichs RJ, Meyer-Lueckel H: Systematic review on noninvasive treatment of root caries lesions. J Dent Res 2015;94:261-271.

Wyatt CC, MacEntee MI: Caries management for institutionalized elders using fluoride and chlorhexidine mouthrinses. Community Dent Oral Epidemiol 2004;32:322-328.

Zero DT, Fu J, Espeland MA, Featherstone JD: Comparison of fluoride concentrations in unstimulated whole saliva following the use of a fluoride dentifrice and a fluoride rinse. J Dent Res 1988;67:1257-1262. 